\title{
Mineraçãão
}

\section{Mining in urban areas: methodological proposal for the identification and mediation of socio- environmental conflicts}

\section{Mineração em áreas urbanas: proposta metodológica para identificação e mediação de conflitos socioambientais}

Denise de La Corte Bacci

Instituto de Geociências.

Universidadede São Paulo.

bacci@igc.usp.br

Tânia Maria Ramos de Godoi Diniz Serviço Social,

Faculdades Metropolitanas Unidas, FMU. tgdiniz@uol.com.br

\section{Resumo}

Os conflitos gerados por mineração, em área urbana, ocorrem devido a diversos motivos. Procurou-se identificar os atores sociais e a dinâmica dos conflitos na região noroeste do município de São Paulo, área que concentra aspectos de preservação ambiental com atividade de pedreiras produtoras de agregados para construção civil, constituindo-se, ainda, em uma região com densa ocupação urbana. Para que esses conflitos sejam minimizados/solucionados, propõem-se estratégias de negociação, de participação e de aprendizagem social.

Palavras-chave: Pedreiras em área urbana, conflitos socioambientais, aprendizagem social, Perus.

\section{Abstract}

The conflicts generated by mining in urban areas are due to several reasons. In this paper we sought to identify the social actors and the dynamics of conflicts in the northwestern region of the São Paulo Municipality. This area presents aspects of environmental preservation, quarry activities, and dense urbanization. To minimizel solve these conflicts, strategies are proposed based on Social Learning methodologies.

Keywords: Quarries in urban areas, Socio-environmental conflicts, Social Learning, Perus, São Paulo. 


\section{Quarries in urban areas and environmental conflicts}

In the northwestern region of São Paulo, four quarries of aggregates for civil construction are currently active. These sites are surrounded by a population of around 500,000 inhabitants and are close to water sources and forest reserves. Quarries are responsible for 25\% of the production of crushed stone of the State of São Paulo (DNPM, 2010; Mechi \&Sanches, 2010). In this region social and environmental conflicts are very common.

The conflicts in the mining areas, particularly in urban areas, include: lack of knowledge and information about the mining activities by the community, generation of environmental impacts and discomfort to the population, disputes over the use and occupation of land, urban expansion and illegal occupations surrounding cave mining. For these conflicts to be handled appropriately, ways to negotiate based on Social Learning are proposed. The methodology proposes seeking ways to establish a dialogue through different strategies: studies on the social representations of the individuals involved in order to capture the senses and meanings designed for the theme, the development of knowledge, reflection and awareness of the local social and environmental issues such as intervention and as method, the clarification of responsibilities and competences of the social actors.

Social Learning means Learning together to manage together. It is based on the principle of de-monopolization of the technicians' knowledge and on learning together how to handle changes in the management of natural resources, with the context, the process and the results being key elements that affect the intervention. Among the Social Learning tools, information management is crucial to achieve the results of the substantially valid processes. The information should be used to equip the population and enable the paths towards dialogue and mediation.

Information management was addressed in this study in the contextualization and discussion of local conflicts with the different actors: maps, satellite images of neighborhoods and historical context were used in this approach. In addition, information regarding the quarry (methods and techniques, blasting, fire plan, crushing, production), on the expansion of the urban settlement of the region (irregular plots, expansion of public urban policy, local site history) and on the actions of local public policies regarding environmental issues was gathered. Thus, we sought to discuss the importance of mining to society particularly for the region, by hearing the opinion of the population, of the government and mining companies on the socio-environmental issues, constituting a local frame of conflicts and possible paths to solutions.

The methodology used aimed to approach different social actors, developing a common vision about the issues under study, through negotiation strategies, participation and education, in order to achieve common solutions for a socioenvironmental management of local natural resources.

\section{São Paulo: mineral resources, land use and occupation, and the environment}

According to Jacobi (1997), in the Metropolitan Region of São Paulo, currently constituted of 39 municipalities, the extensive and uncontrolled process of occupation of the urban space, gives rise to the "non-urbanized" outskirts, which do not have the necessary urban infrastructure and from the practice of space occupation known as self-housing / home ownership / peripheral allotments modalities.

The dynamics of "urbanization through the expansion of suburbs" produced a segregated urban environment and highly degraded with serious consequences for the quality of life of its inhabitants. This occurred after the occupation of unsuitable spaces for housing, precariously constructed in regions needy of urban services. In the municipality of São Paulo, the highest rates of population growth occurred in the peripheral regions, with loss of population in the central districts. The regions of Perus and Pirituba, included in the present study, represent this reality. These areas are exacerbated by the presence of four quarries and environmental problems. The region was one that grew the most in the city in recent years (SEMPLA, 2007).

The expansion of urbanization has been occurring in regions containing natural barriers (areas of water sources, slopes, wetlands, and forest reserves), placing the population in areas of geological, environmental and social risk. According to Jacobi (1997), living conditions in Sao Paulo can be considered to have highly questionable environmental quality. The practices of disordered and irregular occupation of space and the absence of government action produced a number of neighborhoods where a disorganized illogical land use prevails, creating a total precariousness in the quality of life.

In the study area, a situation of significant environmental and social importance is set up, considering the demands for the mineral resources by the aggregate industry and the growing demands of land use for housing. The demand for housing has historically increased over the past two decades, depending on public policies of expansion and encouragement for the acquisition of their own property. These incentives have also led to many private subdivisions, albeit unregulated and many irregular occupations.

The current situation in the region establishes a growing dispute for land use: increase in exploration of mineral resources and urbanization, which is reflected in the environmental conflicts identified.

\section{Social learning: theoretical reference, assumptions and strategies of implementation}

Social Learning emphasizes the collaboration between the different social actors, and encourages dialogue. It motivates the formation of a critical, creative and attuned way of thinking with the need to propose answers for the future, and provides means to be capable of analyzing the complex relationships between the natural and social processes and to act in the environment in a global perspective, respecting the sociocultural diversities (Jacobi et al, 2011). The concept, according to Pahl-Wost (2004) and Wals (2010) addresses the challenges 
of sustainability and can be used in the integration of the management of environmental conflicts interfaces. This assumes the contribution of different types of knowledge, interdisciplinarity and transversality.

The social learning process implies recognition and explanation of the conflicts originated from the environmental conflicts, understanding of the environment as a public good and access to a healthy environment as a right of citizenship. The basic notion of social learning is defined as "learning together to manage together"(HARMONICOP, 2003a).

The Social Learning (SL) methodology sets up an opportunity for social actors to participate in the process of developing their own action plan for mediating conflict (Jacobi et al, 2006), that would promote a collective

\section{Identification of local conflicts}

In contemporary societies, the importance of a particular type of conflict has increased, which revolves around nature or environment or even natural resources. The main issues stand out, such as, the finitude and eventual shortage of some goods (oil, drinking water), air and water pollution, the contamination by toxic substances, the extinction of species and reduction of their natural habitats, the acceleration of the spread of serious infectious diseases, the loss of farmland due to predation practices, the great evils of monocultural farming, deforestation, the greenhouse effect, the weakening of the ozone layer, the risks of nuclear technology, the threats to biodiversity and so on with almost all natural resources (Theodoro, 2005).

Natural resources are not classified as individual private property and therefore its exploration, when affecting a large number of people, requires mechanisms and institutions capable of resolving conflicts between social groups. In the case of mineral resources, they belong to the Federal Government, being a common good to all and explored under a concession set by law.

The identification and analysis of social actors are key elements for the study of conflicts, since they attempt to explain the specific interests at stake at the time of crisis. Table 1 describes the knowledge of a mediator, in a cooperative approach that would lead to an improvement of socio-environmental quality, according to specific strategies, defined as follows:

- Strategy of Negotiation: Negotiation is an important strategy for construction of joint decisions. It is not always possible to build a consensus, but you can always opt for negotiation. The negotiation of the parties involved assumes the same relationship of strength and power from the actors that can offer strategies of knowledge, institutionalization, and joint intervention.

- Strategy of Participation: Participation is one of the fundamental elements in the sequence of negotiations among multiple actors. Therefore, the increasing involvement and joint learning of the participating

social actors identified in the study area and their view of the local environmental conflicts.

Considering the study area, we can define two main types of conflict occurring, as described by Litlle (2004):

- Conflict over land use

- Conflict for the environmental impacts generated by the method of extraction.

These types of conflicts involve the responsibility of: mining companies, government and community.

The necessity of land use for housing is urgent in the region. Absence of effective actions from the government over the years to address the housing demand in the region is observed. The regularization of some occupied areas provided for the invasion of adjacent areas, which resulted in disorderly occupation in the vicinity of quarries and in the progress towards the environmental preservation area.

The conflict for environmental impact generation comes from the mining method used by quarries, characterized as blasting and transportation. Such activity generates ground vibration, air blast, noise, dust and gases, which are considered to be the main impacts that generate discomfort for the population. The blast vibration is felt in the residences at a distance of 200 meters upfront. Measurements with engineering seismograph vary actors in the management of natural resources enhance the strategy of learning together to intervene together. The socio-environmental crisis can be resolved through the negotiation of conflicts.

- Educational Practice: Strategies for Implementation: these practices are based on: Promoting a problem-solving attitude, a complex understanding and politicization of environmental issues, participation of subjects, to explicit an emphasis on less rigid social practices, focused on cooperation between the actors. Therefore, the environmental dimension represents the possibility of handling connections between different human spheres, twists and multiple transits between different types of knowledge (Jacobi et al, 2006).

depending on the direction of the front mining, with the charge used, and with the distance. The residents can feel the tremors as the wave passes through the ground. Since they cannot evaluate whether they are or not at risk, they report fear at whatever blasting can do to their houses. The air blast shakes windows according to reports from residents. Noise, dust and gases are produced by blasting and by the intense traffic of trucks on roads. The winds in the region direct part of the fumes and dust to the residences, which generate many complaints and some cases of lung disorders.

Although this region is near to a State Natural Park (Serra da Cantareira), residents complain about the lack of leisure places and invade mining properties for some pleasure and entertainment (to swim, to fish and to make trails). The process of urbanization did not allow for recreational areas (squares, soccer fields and playgrounds), which contribute to the conflicts. Table 2 presents the dynamics of local conflicts (based on Theodoro, 2005).

From the data collected in the field, we then have several visions of conflict and the possibility of establishing strategies of approach to satisfy the expectations of the community, mining companies and the government. Table 3 presents strategies for mediation of local conflicts. 


\begin{tabular}{l|l}
\hline $\begin{array}{c}\text { Identification of } \\
\text { social actors }\end{array}$ & \multicolumn{1}{c}{ Current view of the conflicts } \\
\hline Companies \\
(Quarries) & $\begin{array}{l}\text { Actions in companies are based on the compliance of the environmental and mineral } \\
\text { legislation for the environmental permits, with few pro-active actions. There is a posture } \\
\text { of detachment from the community, protection of information related to the activities } \\
\text { of quarrying and assistencialism in the development of social projects, of which the } \\
\text { community is not consulted and does not participate in its implementation. While } \\
\text { acknowledging the conflicts with the community, the companies do not yet know how } \\
\text { to deal with participatory approaches that involve the community and the government } \\
\text { in the forms of management. } \\
\text { The relationship with the community is configured in the attending of complaints and } \\
\text { monitoring of impacts at the residences of the complainants. The relationship with } \\
\text { the government is to meet the legal requirements and the demands for monitoring and } \\
\text { providing local services. }\end{array}$ \\
\hline Government & $\begin{array}{l}\text { Promoter of little effective actions to contain the irregular use of soil in the region and } \\
\text { in relation to the illegal occupations that have already occurred and the needs of the } \\
\text { population; lack offinancial resources to improve local infrastructure, lack oftechnicians } \\
\text { to diagnose and treat local problems; treatment based on complaints, which } \\
\text { constitutes a dialogue channel, and in reactive rather than preventive measures. The } \\
\text { quarry activity supervision is under responsibility of the state agency. The relationship } \\
\text { with the community is a conflicting one, before actions of disappropriation and land } \\
\text { regularization. }\end{array}$ \\
\hline $\begin{array}{l}\text { Little or no technical knowledge about the activities of quarrying, mining and } \\
\text { environmental legislation and the acts of government, thus aggravating the conflict and } \\
\text { undermining the negotiations. It appears somewhat disjointed and little participatory. } \\
\text { It does not take a side as a participant of the problems, assigning the responsibility of } \\
\text { conflicts to the businesses and the government. Still not ready to discuss the problem } \\
\text { at its source, which is the soil occupation; still have a great concern with the local } \\
\text { infrastructure and with the regularization of housing, and other basic needs. }\end{array}$ \\
\hline
\end{tabular}

\section{Elements}

of conflict

The conflict involves the following areas: economic (society's need for minerals), social (discussing about environmental discomfort, land use and occupation) politics (lack of public policies and effective government programs regarding invasions of protected areas); environmental (concerns about the level of ground vibration, air blast and pollution (dust, gases and fumes), visual pollution, degradation and remediation of mined site, preservation of protected areas (native forest, water sources and hilltops' slopes). Field municipal and state supervision and legislation. The reproduction of these conflicts in other areas in the city and also on a national scale is observed.

Favorable to closure of quarries activities at the site (residents' association, NGOs, local civil and religious organizations).

Favorable to a better supervision and control of quarry activities, recognizing its importance

Actors in generating jobs, for the economy and a necessity for society (community and government members, supervision agents).

Favorable to the maintenance of the current situation and to an improvement in the relationship with the community and with the government, believing in the power of new technology for the exploitation of minerals resources and mitigation of environmental impacts.

The object of dispute is the use of land: on one hand the progress of the quarries and a larger need for exploration areas, some of them closer to the residences, and for the environmental impacts caused by the mining method using explosives in rock blasting for quarries. On the other hand, private housing not yet settled by the government and invasions of water source and geologically risky areas is increasing, coming closer to the quarries.

The conflict is presented between groups with divergent views on the use of physical space in the region. This conflict has occasional moments, with resident complaints being made to the supervising environmental agencies and actions from these organs in response to the population. However, these events are summed up to a few detonations that the quarries do. There is no continuous monitoring, in order to provide ongoing information to the public about the activity and impacts of quarries. As the extraction fronts advance and the areas are occupied by houses, the conflict on the environmental impacts changes place, reaching residents in different neighborhoods, creating a dynamic of conflict location. In this case, the location of the active mining front and the planning of occupations should be monitored for the resolution of conflicts, which directly involves the government. The control of the land occupation involves the population and the government at the municipal, state and federal level, with a more complex and difficult to solve dynamics, since it involves political, economic and social matters.
Table 1

Identification of social actors and analysis of the socio-environmental conflict viewpoints.
Table 2

Dynamics of the local conflict. 


\begin{tabular}{|c|c|}
\hline $\begin{array}{c}\text { Identification } \\
\text { of social } \\
\text { actors }\end{array}$ & Analysis of current situation and ways to mediate conflicts \\
\hline $\begin{array}{l}\text { Companies } \\
\text { (Quarries) }\end{array}$ & $\begin{array}{l}\text { Development of activities with community participation, listening to their suggestions, ideas } \\
\text { for improvements and not just their complaints. A greater transparency in the activities and } \\
\text { better communication with community, always seeking security. This may contribute to inform } \\
\text { the population about their activities and, especially, about its importance for social and } \\
\text { economic development of the region, establishing better channels of dialogue. Clarifying the } \\
\text { process of mineral extraction and production would be a way for the mediation of conflicts. } \\
\text { It is also important that the mining sector understands their role in society, which is deeply } \\
\text { involved with the problem of negative perception of their activities by public opinion. In the } \\
\text { study area, this could be corroborated with the analysis of questionnaires in the community, in } \\
\text { which more than } 80 \% \text { of respondents were unaware of the activities of quarrying and yet they } \\
\text { attribute the existent conflicts to them (Bacci et al, 2011). }\end{array}$ \\
\hline Government & $\begin{array}{l}\text { There is a lack of long-term local policies to define the priorities of the region which are } \\
\text { not the same in other regions of municipality. Poor surveillance and environmental control } \\
\text { practices that do not promote minimization or avoid conflicts. Participation in community } \\
\text { awareness of local problems and prevention of risk is still insufficient, hindering dialogue. } \\
\text { Preventive measures and guidelines in the management of administrative sub-districts could } \\
\text { help to minimizze conflicts of irregular occupation. National government policies in the area } \\
\text { of housing, allowing construction in areas near the quarries also contribute to increasing local } \\
\text { conflicts. }\end{array}$ \\
\hline Community & $\begin{array}{l}\text { The communication between social actors is deficient. The community does not have } \\
\text { information about the positive and negative impacts of quarrying activities, feeding myths } \\
\text { and negative aspects of ventures. The same occurs with the environmental aspects of the } \\
\text { irregularly occupied areas and settlements. The technical capacity of residents can foster } \\
\text { dialogue with other social actors. There is a need to awaken in the involved individuals } \\
\text { a greater awareness and participation in relation to the importance and characteristics of } \\
\text { mining and local environmental issues. The understanding of complexity of the process as a } \\
\text { whole, feeling a part of the problems, as active subjects of the local historical processes, can } \\
\text { facilitate dialogue and ways to improve relations with the government and the quarries. This } \\
\text { understanding will give public subsidies to address the issues of conflict. }\end{array}$ \\
\hline
\end{tabular}

Proposal for mediation of local conflicts.

\section{Conclusions}

One of the aspects that increase conflicts in urban areas where mining is predominant is when government and society have an immediate and fragmented vision, which seek to "solve a problem", without considering that other problems may arise. A complex view is necessary when environmental issues are considered. Also, partial and short-term solutions postpone or extend the conflicts.

Social learning strategies proved to be adequate in the mediation of conflicts in this study case. From the studies, however, we point out that the actors are

\section{Acknowledgments}

The authors thank FAPESP for the not yet prepared to discuss and negotiate conflicts considering the complexity of the perspective. The paths for mediation of conflicts require that educational and informative strategies be applied to the different social actors, being still needed:

- To promote a shared and complex view of the conflicts among all social actors within a context of cooperation and not individuality.

- To promote changes in the conception of companies and government, to broaden the understanding of conflicts as well as legislation and technology.

- To foster the technical and scientific knowledge of the local community, to extend their participation in natural resource management.

The results point to a continuous process, because as actors perceive more, they participate more and acquire more possibilities of negotiation. Since a shared understanding of the complexity of the process is that social actors may find ways to solve or minimize the environmental conflicts. For a socioenvironmental sustainability, solutions must be collaborative and participatory. This takes time and willingness to dialogue and negotiate.

financial support (Auxílio à Pesquisa - Process 2008/51271-6).

\section{References}

BACCI, D.C., DINIZ, T.M.R.G, AQUINO, T.D.V.S. Diagnóstico socioambiental da atividade de mineração, na região noroeste do município de São Paulo relacionamento com a comunidade e o poder público. Revista Geociências , v. 30, n. 2, p.207-217. 2011.

DNPM Departamento Nacional de Produção Mineral. Sumário Mineral 2010. www. dnpm.gov.br Acesso em: 20 de janeiro de 2011. 
HARMONICOP. Public participation and the European water framework directive: role of information and communication tools. WorkPackage 3 report of the HarmoniCOP, 2003a.128p.

JACOBI, P.R. Meio ambiente urbano e sustentabilidade: alguns elementos para a reflexão. In: CAVALCANTI, C. (Org.). Meio ambiente, desenvolvimento sustentável e políticas públicas. Paulo:Cortez, 1997.

JACOBI, P.R., GRANJA, S.I.B., FRANCO, M.I.G.C. Aprendizagem social: práticas educativas e participação da sociedade. São Paulo em Perspectiva, v. 20, n. 2, p. 5-18, 2006.

LITTLE, P.E. A ecologia política dos conflitos em torno da pesca na Amazônia. In: SEMINÁRIO META: AS TRANSFORMAÇÕES SOCIOAMBIENTAIS NA AMAZÔNIA E AS SUAS CONSEQUÊNCIAS, 2. Brasília, 2003. CD-Rom.

MECHI, A., SANCHES, D.L. Impactos ambientais da mineração no Estado de São Paulo. Estudos Avançados, v. 24, n. 68, p. 209-220, 2010.

PAHL-WHOSTL, C. HARE, M. Processes of social learning in integrated resources management. Journal of Community \& Applied Social Psychology, Wiley, v. 14, n. 3, p.193-206, 2004.

Secretaria Municipal de Planejamento (SEMPLA) da Prefeitura de São Paulo. Município em Dados. 2007. (http://www.prefeitura.sp.gov.br/cidade/secretarias/ planejamento/)

THEODORO, S.H. (Org.) Mediação de conflitos socioambientais. Rio de Janeiro: Editora Espaço e Tempo, 2005. 217 p.

WALS, A.E.J. (org.). Social learning towards a sustainable world: principles, perspectives, and praxis. Wageningen: Wageningen Academic. Publishers, 2007. $357 \mathrm{p}$.

Artigo recebido em 16 de maio de 2012. Aprovado em 28 de março de 2013. 